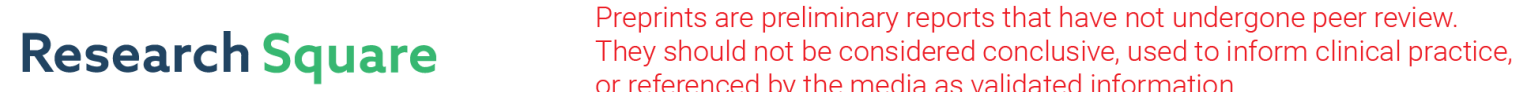 or referenced by the media as validated information. \\ Physicochemical Properties of Shea Butter Synthesized Biodiesel
}

\section{IFEANYI GODWIN OKOYE}

DEPARTMENT OF BIOCHEMISTRY, RENAISSANCE UNIVERSITY, UGBAWKA, ENUGU STATE, NIGERIA

CHUKWUMA STEPHEN EZEONU ( $\nabla$ chuksmaristos@yahoo.com )

Federal University Wukari

\section{ELIZABETH KIGBU DANLAMI}

DEPARTMENT OF BIOCHEMISTRY, RENAISSANCE UNIVERSITY, UGBAWKA, ENUGU STATE, NIGERIA

\section{Research}

Keywords: Biodiesel, Physicochemical, Shea, Synthesize, Transesterification

Posted Date: October 5th, 2020

DOl: https://doi.org/10.21203/rs.3.rs-72342/v1

License: (1) This work is licensed under a Creative Commons Attribution 4.0 International License. Read Full License 


\title{
Physicochemical Properties of Shea Butter Synthesized Biodiesel
}

\section{${ }^{1}$ Ifeanyi Godwin Okoye, ${ }^{2}$ Chukwuma Stephen Ezeonu ${ }^{*}$, and ${ }^{1}$ Elizabeth Kigbu Danlami \\ ${ }^{1}$ Department of Biochemistry, Renaissance University, Ugbawka, Enugu, Nigeria. \\ ${ }^{2}$ Department of Biochemistry, Federal University Wukari, Taraba State Nigeria.}

*Correspondence: Ezeonu, C. S. chuksmaristos@yahoo.com, +2348066919780

\begin{abstract}
Base - catalyzed transesterification of Shea (Vitellaria paradoxa) seed fat was carried out at a methanol/oil ratio of $5: 1(\mathrm{~V} / \mathrm{V})$ at $70^{\circ} \mathrm{C}$ to synthesize the corresponding methyl esters (biodiesel). The percentage yield of approximately $87 \%$, was recorded after ninety minutes, indicating that Shea fat is a good biodiesel feedstock. The physicochemical properties of the Shea biodiesel were determined. The colour was pale yellow while the relative density $\left(870 \mathrm{Kg} / \mathrm{m}^{3}\right)$, kinematic viscosity $\left(2.66 \mathrm{~mm}^{2} \mathrm{~s}^{-1} 40^{\circ} \mathrm{C}\right)$, acid value $(0.19 \mathrm{mg} \mathrm{KOH} / \mathrm{g})$, peroxide value $(0.52 \mathrm{meq} / \mathrm{kg})$ and cetane number (68.10) were observed. The cloud point was found to be $9.3^{0} \mathrm{C}$, while the flash point of $156.67^{\circ} \mathrm{C}$, iodine value of $35.29 \mathrm{mg} / 100 \mathrm{~g}$ and energy value of $39.3 \mathrm{MJ} / \mathrm{Kg}$ were recorded. All these value compare well with previous works and are within acceptable limits as specified by the American Society for Testing and Materials (ASTM). The current research indicated that Shea butter has biodiesel potential aside its uses in culinary and cosmetics applications.
\end{abstract}

Keywords: Biodiesel, Physicochemical, Shea, Synthesize, Transesterification 


\section{Introduction}

Shea tree has been identifies as native to over sixteen west African countries (Benin, Burkina Faso, Cameroon, Central African Republic, Chad, Cote d'lvoire, Ethiopia, Ghana, Guinea, Mali, Niger, Nigeria, Senegal Sudan, Togo and Uganda) and found growing wildly in many Nigerian states (Niger, Nasarawa, Kebbi, Kwara, Kogi, Adamawa, Benue, Edo, Katsina, Plateau, Sokoto, Zamfara, Taraba, Borno and Oyo) (Ekeh, 2010). Oil and butter being components of shea nuts from the shear tree Vitellaria paradoxa formally Butryospermium paradoxum (Warra, 2011), has found many usefulness inclusive but not exhaustive in the production of creams, pharmaceutical, paint, vanish, animal feed, soap, confectionery products, wood polish and of recent biodiesel. Production of biodiesel using various catalytic processes has been researched viz: homogenous catalyst method (Ejeh and Aderemi, 2014), catalyzed and supercritical transesterification synthesis processes (Odisu et al., 2019), and transesterification reaction under different operational conditions of temperature, reaction time and catalyst ( $\mathrm{NaOH}$ ) (Yaro et al., 2019) among others. The current research involve synthesis and establishment of the physicochemical properties of biodiesel from Nasarawa Eggon shea butter popularly sold in the Mada Station Market of Nassarawa State, Nigeria. Biodiesel being fuel generated from plants and plant based materials is seen as a better option for the future as it is not only environmental friendly compared to the fossil stock but also renewable.

\section{Materials and Methods}

\section{Shea butter Source}

The shea butter (which is the main feedstock for biodiesel production) was purchased from Mada Station Market, Nasarawa Eggon Local Government Area of Nasarawa State, Nigeria

\section{Shea Biodiesel Production}

A five hundred millilitre three-necked round-bottomed flask was used as the reactor for the transesterification reaction. Shea butter fat was first molten and a volume $(500 \mathrm{ml})$ of $470 \mathrm{~g}$ weight was measured into the reactor and preheated at $50^{\circ} \mathrm{C}$ for 30 mins. Methoxide $(100 \mathrm{ml})$ solution prepared by dissolving $4.25 \mathrm{~g}$ of $\mathrm{KOH}$ in hundred millilitres of methanol, was added and 
fitted with a condenser. The temperature was raised to $70^{\circ} \mathrm{C}$ maintaining continuous stirring with a magnetic spin stirrer. After 90 mins, the reaction mixture was slightly acidified with $1 \mathrm{M} \mathrm{H}_{2} \mathrm{SO}_{4}$ solution to neutralize the base, and transferred to a separating funnel. Biodiesel separation was carried out by addition of warm distilled water on the mixture, which was then left to stand overnight. A dark brown coloured, cloudy denser lower layer (glycerol and soap) was tapped off leaving a light yellow upper layer (biodiesel). The biodiesel was concentrated and its fuel properties were determined.

\section{Characterization of Shea Biodiesel}

\section{Determination of density/relative density}

The biodiesel was determined according to a method described by Onwuka (2018). A pycometer (density) bottle of $50 \mathrm{ml}$ capacity was thoroughly washed with detergent, water and petroleum ether, dried and weighed. The clean dry pycometer bottle was filled with $50 \mathrm{ml}$ of synthesized biodiesel and weighed again. Weighed biodiesel was gotten by subtracting the weight of bottle from the weight of biodiesel and density bottle. Density was determined by taking the ratio of the weight of the biodiesel to the known volume $(50 \mathrm{ml})$ according to the formula:

$$
\text { Density }=\frac{\text { Biodiesel Weight }}{\text { Biodiesel Volume }}
$$

Specific gravity was also determined using the $50 \mathrm{ml}$ capacity pycometer bottle .The weight of the empty bottle and that of $50 \mathrm{ml}$ of biodiesel had been taken earlier. Now, after washing the bottle and dry,the bottle, it was filled with water $(50 \mathrm{ml})$ and weighed . Specific gravity was calculated using the formula: ‘

$$
\text { Specific Gravity = Weight of Biodiesel }(50 \mathrm{ml}) / \text { Weight of Water }(50 \mathrm{ml})
$$

\section{Determination of Refractive index}

Refractive index was determined using a digital table top refractometer (HI96800) manufactured by Hanna Instruments, Romania. The device was initially calibrated to zero using distilled water. The biodiesel was then placed at the glass prism and the refractive index read off.

\section{Determination of Moisture}


Dry oven method moisture determination by Wick (1985) was used. Synthesized biodiesel (5g) was weighed into an already weighed petri dish (a). The sample in petri dish was transferred into an oven and left for an hour at $105^{\circ} \mathrm{C}$. The sample was allowed to cool in a desiccator. The second weight of the biodiesel was taken after oven heating (b). Percentage moisture was calculated using the formula:

$\%$ Moisture $=\frac{a-b}{\text { Initial Sample weight }} \times 100 \%$

\section{Determination of Saponification Value}

Saponification value was determined according to the method of Boerlage and Broeze, (1990). This is the milligram of $\mathrm{KOH}$ required to neutralize the fatty acids resulting from the complete hydrolysis of $1 \mathrm{~g}$ of the sample. Saponification value is the measure of the molecular weight of the fatty acid. Briefly, a quantity $(0.5 \mathrm{~g})$ of the biodiesel was weighed into a conical flask and $50 \mathrm{ml}$ of $0.5 \mathrm{~N}$ ethanolic $\mathrm{KOH}$ was added to it. The mixture was refluxed to saponify the sample. The unreacted $\mathrm{KOH}$ was titrated back with $0.5 \mathrm{~N}$ hydrochloric acid using three drops of phenolphthalein as indicator. The saponification value of the biodiesel was calculated thus:

\section{Saponification Value $=\frac{(\text { Titre Value })(\text { Nomality of } \mathrm{NaOH})(56.1)}{(\text { Weight of Biodiesel })}$}

\section{Determination of Kinematic Viscosity}

U-tube viscometer manufactured by Poulten Selfe and Lee Ltd (PSL ASTM-IP 350) was used to determine the kinematic viscosity of the shea biodiesel. Micropipette was used to introduce the sample into the viscometer. Sample flow time was determined in seconds at $40^{\circ} \mathrm{C}$.

Kinematic Viscosity $=c t\left(\mathrm{~mm}^{2} \mathrm{~s}^{-1}\right)$

Where $\mathrm{c}$ is viscosity constant 0.4891

\section{Determination of Acid Value}

The acid value which is the number of milligram of $\mathrm{KOH}$ required to neutralize the free fatty acid in $1 \mathrm{~g}$ of the biodiesel sample was determined according to ASTM (2002). Briefly, shea biodiesel $(0.5 \mathrm{~g})$ was weighed into a conical flask and $20 \mathrm{ml}$ of ethanol and three drops of 
phenolphthalein indicator added. Titration of the solution with constant agitation was carried out until a faint, pink end point which persists for thirty seconds appeared. The volume of the titrant at end point was recorded. From the readings obtained, the acid value was evaluated using the equation below:

$$
\text { Acid Value }=\frac{(\text { Acid Titre Value })(\text { Nomality of } \mathrm{NaOH})(56.1)}{(\text { Biodiesel Weight })}
$$

\section{Determination of Peroxide Value}

Peroxide value was determined according to the method of Boerlage and Broeze (1990). The peroxide value is the measure of the peroxides contained in the oil. Glacial acetic acid (25ml) and chloroform were mixed together in the ratio $2: 1$ into a conical flask added to $0.5 \mathrm{~g}$ of synthesized biodiesel. A volume $(1 \mathrm{ml})$ of $10 \%$ potassium iodide solution was added shaken vigorously, covered and kept in the dark for one minute after which starch indicator (35ml) was added. The whole solution $\left(\mathrm{V}_{1}\right)$ was titrated with $0.02 \mathrm{~N}$ sodium thiosulphate solution as it turned from pale black to white. Titration was also carried out on the blank. Peroxide value was calculated from the equation below:

$$
\text { Peroxide Value }=\frac{(100)(\text { V1 }- \text { V2 })(\text { Normality of Titrant })}{(\text { Sample Weight })}
$$

\section{Determination of Iodine Value}

Boerlage and Broeze (1990) described the protocol employed in this research. Briefly, 15ml of chloroform was added to $0.5 \mathrm{~g}$ of synthesized biodiesel. To the resulting mixture was added $25 \mathrm{ml}$ of Wiji's solution, and vigorously agitated. The mixture was covered tightly and placed in the dark cupboard for thirty minutes. Measured volume $(20 \mathrm{ml})$ of $10 \% \mathrm{KI}$ was added followed by $150 \mathrm{ml}$ of distilled water. Resultant red colouration was observed after which $5 \mathrm{ml}$ of $5 \%$ starch solution indicator was added and observed for blue-black colour change. The solution was titrated with $0.1 \mathrm{~N}$ sodium thiosulphate solution until black precipitates appear in colorless solution. Titration was also made for the blank. Iodine value was calculated as:

$$
\text { Iodine Value }=\frac{(12.69)(V 2-V 1)(\text { Normality of Titrant })}{(\text { Weight of Biodiesel })}
$$

\section{Determination of Cloud Point}


The synthesized biodiesel sample was placed in a medium sized test tube and the test tube with its content placed in a test tube rack and placed in a refrigerator and monitored. The temperature at which the heavier components formed mass of colloids is the cloud point. This temperature was determined using mercury-in-glass thermometer.

\section{Determination of Flash/Fire point}

Flash (fire) point were determined by pouring the biodiesel sample in a glass petri dish so that the surface of the dish was covered. A mercury-in-glass thermometer was immersed into the sample in the petri dish so that the tip of the thermometer just touched the biodiesel sample. The thermometer was held in position using a retort stand and clamp. The sample was placed on a laboratory heating mantle and was gradually heated and light source was applied at intervals. The lowest temperature at which the sample just ignited' and went off was recorded as the flash point.

\section{Determination of Aniline point}

Aniline point was determined according to ASTM (2004). Aniline oil was poured into a test tube. The shea biodiesel sample was also introduced into the test tube. Both samples were initially not mixable and so formed double phase. The test tube was placed in a test tube rack and placed in a refrigerator. The lowest temperature at which the aniline oil and biodiesel mixed together was recorded as the aniline point.

\section{Determination of API gravity}

The American Petroleum Institute (API) gravity was determined from the value of the specific gravity of the biodiesel using the formula:

$$
\left.A P I=141.5 / \text { Specific Gravity at } 60^{\circ} \mathrm{F}\right)-131.5
$$

\section{Determination of Cetane index/Cetane number}


The cetane index is a measure of the ignition quality of diesel fuel. The higher the cetane index, the easier it is to start a standard diesel engine. Cetane index determined according to the method of Boerlage and Broeze (1994). Using the formular:

$$
\text { Cetane Index }=\frac{\text { Aniline Point }\left({ }^{\circ} \mathrm{C}\right) \times \text { API Gravity }}{10}
$$

\section{Determination of Energy Value}

The energy value was determined using a bomb colorimeter. After standardization of the biodiesel with benzoic acid, a quantity $(0.5 \mathrm{~g})$ of the biodiesel was burned in the calorimeter and values taken. Measurements were repeated three times.

\section{Characterization of Shea butter}

Very essential characterization properties determinations carried out in the synthesized biodiesel were equally repeated with shea butter samples.

\section{Statistical Analysis}

Data obtained were expressed as mean \pm standard deviation (SD).

\section{Results}

\section{The Physicochemical properties of the Shea Biodiesel.}

The physicochemical properties of Shea biodiesel and those expected of standard biodiesels are presented in Table 1. All the fuel properties of Shea biodiesel such as density $(0.87 \pm 0.002$ $\left.\mathrm{kg} / \mathrm{m}^{3}\right)$, specific gravity $(0.88)$, acid value $(0.19 \mathrm{mgKOH} / \mathrm{g})$, cloud point $\left(9.33^{0} \mathrm{C}\right)$, kinematic viscosity $\left(2.66 \mathrm{~mm}^{2} / \mathrm{s}^{-1}\right)$, flash point $\left(156.67^{0} \mathrm{C}\right)$, cetane number $(68.10)$ and energy value $(39.3 \mathrm{MJ} / \mathrm{Kg})$ all fell within the acceptable range for standard biodiesels. 
Table 1: The Physicochemical Properties of synthesized Shea Biodiesel values compared with the Standard Biodiesel (Values/Range).

\begin{tabular}{|c|c|c|}
\hline Properties & $\begin{array}{l}\text { Shea Biodiesel } \\
(\text { Mean } \pm \text { SD) }\end{array}$ & $\begin{array}{l}\text { Standard Biodiesel } \\
\text { (Values/Range) }\end{array}$ \\
\hline Density $\left(\mathrm{Kg} / \mathrm{m}^{3}\right)$ & $870 \pm 2.15$ & 575 to 900 \\
\hline Specific gravity & 0.88 & 0.88 \\
\hline Refractive index @ $29^{0} \mathrm{C}$ & 1.46 & - \\
\hline Moisture (\%) & Nil & $<0.05$ \\
\hline $\begin{array}{lll}\text { Saponification } & \text { value } & \text { (mg } \\
\mathrm{KOH} / \mathrm{kg}) & \end{array}$ & $184.18 \pm 0.25$ & \\
\hline Viscosity@400 C $\left(\mathrm{mm}^{2} \mathrm{~s}^{-1}\right)$ & 2.66 & $1.9-6.0$ \\
\hline Acid value (mg KOH/g) & $0.19 \pm 0.01$ & $<0.5$ \\
\hline Peroxide value (meq/kg) & $0.52 \pm 0.01$ & - \\
\hline Iodine value $(\mathrm{mg} / \mathbf{1 0 0 g})$ & $35.29 \pm 0.94$ & - \\
\hline Cloud point $\left({ }^{0} \mathrm{C}\right)$ & $9.33 \pm 0.29$ & -3 to 12 \\
\hline Flash point $\left({ }^{0} \mathrm{C}\right)$ & $156.67 \pm 1.53$ & $100-170$ \\
\hline Aniline point & 23 & - \\
\hline API gravity & $29.61 \pm 0.93$ & - \\
\hline Cetane index & $68.10 \pm 2.15$ & 47 minimum \\
\hline Specific gravity & 0.88 & - \\
\hline Energy value (MJ/Kg) & 39.3 & $40-50$ \\
\hline
\end{tabular}


American Society for Testing and Material (ASTM) D6751 for biodiesels.

Table 2: The Physicochemical Properties Value of Shea Butter

\begin{tabular}{|c|c|}
\hline Properties & Shea Butter Mean \pm SD \\
\hline Viscosity at $40^{\circ} \mathrm{C}\left(\mathrm{mm}^{2} \mathrm{~s}^{-1}\right)$ & $114.40 \pm 1.58$ \\
\hline Density $\left(\mathrm{kg} / \mathrm{m}^{3}\right)$ & $920 \pm 0.003$ \\
\hline Energy Value (MJ/Kg) & 33.9 \\
\hline- & - \\
\hline Cloud Point $\left({ }^{\circ} \mathrm{C}\right)$ & 24 \\
\hline Acid Value (mgKOH/g) & $0.47 \pm 0.02$ \\
\hline Flash Point $\left({ }^{\circ} \mathrm{C}\right)$ & $339.33 \pm 2.08$ \\
\hline Perioxide Value (meq/kg) & $0.85 \pm 0.02$ \\
\hline $\begin{array}{l}\text { Saponification Value } \\
\text { (mgKOH/Kg) }\end{array}$ & $181.98 \pm 0.48$ \\
\hline Iodine value $(\mathrm{mg} / \mathbf{1 0 0 g})$ & $31.19 \pm 0.56$ \\
\hline Refractive index at $29^{\circ} \mathrm{C}$ & $1.47 \pm 0.48$ \\
\hline Moisture & $0.10 \pm 0.01$ \\
\hline
\end{tabular}


The values are presented as mean \pm standard deviation

\section{Discussion}

The yield of Shea biodiesel synthesized with methanol was $87 \%$. The results of the characterization of the shea biodiesel are presented in table 1. The properties determined include: Density, acid value, specific gravity, iodine value, moisture content, cloud point, flash point, peroxide value, energy value, cetane index, saponification value, kinematic viscosity, refractive index, aniline point, API gravity.

Density is an indicator of the physical thickness of solid, liquid or gas measured by its mass per unit of volume. The density of the shea biodiesel produced was $870 \mathrm{~kg} / \mathrm{m}^{3}$. The finding from this research also conforms to the value range (575 - 900) specified by American Society for Testing and Materials (ASTM) D6751 and European Standard (EN) 14214 (Jenvanitpanjakul, 2009) as well as $887.61 \mathrm{~kg} / \mathrm{m}^{3}$ (Datti et al., 2020) from similar research. The density $\left(920 \mathrm{Kg} / \mathrm{m}^{3}\right)$ of the shea butter itself is above the recommended limits and different from the value $\left(895.4 \mathrm{~kg} / \mathrm{m}^{3}\right)$ obtained by Ejeh and Aderemi, (2014) in their research.

The specific gravity of the shea biodiesel was 0.88 which is agreement with the finding of Odisu et al. (2019). They produced biodiesel from shea butter using acid-catalysed transesterification and recorded a value of 0.87 . The specific gravity obtained from the current research also agrees with values of previous work: 0.90 (Ejeh and Aderemi, 2014), and is in conformity with the specification by the American Society for Testing and Materials (ASTM) D6751 and (EN) 14214 (Jenvanitpanjakul, 2009) for biodiesels.

Acid value is the mass of potassium hydroxide in milligram that is required to neutralize one gram of a chemical substance. It is an indicator for the level of free fatty acid in a biodiesel or oil sample. An acid value of $0.19 \mathrm{mg} \mathrm{KOH} / \mathrm{g}$ was obtained for the shea biodiesel produced. This value also conforms to that (0.5 maximum) specified by the American Society for Testing and 
Materials (ASTM) D6751 and (EN) 14214 (Jenvanitpanjakul, 2009) as well as $0.37 \mathrm{KOH} / \mathrm{g}$ (Datti et al., 2020). The acid value $(0.47 \mathrm{mg} \mathrm{KOH} / \mathrm{g}$ ) was also in normal range in the stock (shea butter) table 2 .

Iodine value is the mass of iodine in grams that is consumed by 100 grams of a chemical substance. It is used to determine the degree of unsaturation of fatty acids present. Iodine value of the shea biodiesel was found to be $35.29 \mathrm{mg} / 100 \mathrm{~g}$ similar to $34.24 \mathrm{mg} / 100 \mathrm{~g}$ by Datti et al. (2020) as well as $76.14 \mathrm{mEq} / \mathrm{g}$ by Ejeh and Aderemi (2014) conforming to American Society for Testing and Materials (ASTM) D6751 and (EN) 14214 International Standard. The value from the shea butter stock was $31.19 \mathrm{mg} / 100 \mathrm{~g}$ thus illustrating that the synthesized biodiesel is more unsaturated than its source.

Moisture is the presence of a liquid, especially water, often in trace amounts or amount of water vapour present in the air. Moisture of the shea biodiesel was $0.06(\%)$ which is slightly higher than $(0.05 \%)$ specified by the American Society for Testing and Materials (ASTM) D6751 and (EN) 14214 International Standard. The cause of this disagreement is not traceable to an error in the main process of the product synthesis but rather in downstream processing where the moisture would have been retained. It also depends on the level of synthesized shea butter biodiesel yield during concentration of product which could differ between researcher and varied methodologies adopted. Further concentration of the shea biodiesel can address this problem.

Cloud point refers to the temperature below which wax in diesel or biodiesels forms a cloudy appearance. Cloud point of the shea biodiesel was $9.33^{\circ} \mathrm{C}$ and fell within the specifications by ASTM D6751 and (EN) 14214 International Standard (Jenvanitpanjakul, 2009).

Flash point is the lowest temperature at which vapours of the material will ignite, when given an ignition source or when exposed to a spark of flame. This property is one of the main properties of fuels and determines the likelihood or tendency of a fuel sample to ignite accidentally. It therefore expresses how safe the storage and handling of the sample is. The flash point of the shea biodiesel from this research was $156.67^{\circ} \mathrm{C}$ whereas $110^{\circ} \mathrm{C}$ and $96{ }^{\circ} \mathrm{C}$ were reported by Ejeh and Aderemi, (2014) and (Datti et al., 2020) respectively. These value recorded in the current research is quite in conformity to that $\left(93^{\circ} \mathrm{C}\right.$ minimum) specified by ASTM) D6751 and (EN) 14214 International Standard (Jenvanitpanjakul, 2009). The result from this research showed that there is more stability and safety of the synthesized biodiesel from shea butter against possible ignition. It is thus indicative of a high value biodiesel. 
Peroxide value is widely used to measure the extent which an oil or biodiesel sample has undergone primary oxidation. Peroxide value of the shea biodiesel was $0.52 \mathrm{meq} / \mathrm{kg}$. This is a good property since this value is minimal indicating non rancidity formation of the synthesized product. The aniline point was 23. Refractive index from the synthesized work was 1.46 very comparable to 1.441 by Datti et al. (2020).

Energy value it is expressed in $\mathrm{K}$ calories (Kcal) and in Kilo Joules (KJ). It is important in knowing the heat of combustion not only of foodstuff but also of any combustible material. Energy value of the shea biodiesel was $39.3 \mathrm{MJ} / \mathrm{Kg}$ which is very close to that from a previous work by Ejeh and Aderemi, (2014) who reported an energy value of $37.2 \mathrm{MJ} / \mathrm{kg}$ for their own shea biodiesel. The value from this work is though lower but do not deviate significantly from the range (40 - 50) specified by ASTM and EN (Jenvanitpanjakul, 2009).

Cetane number is an indicator of the combustion speed of diesel fuel and compression needed for ignition. It is an inverse of the similar octane rating for gasoline and is important in delay period of fuels. Cetane number of the shea biodiesel was 68.10 and conforms to ASTM) D6751 and (EN) 14214 International Standards (Jenvanitpanjakul, 2009) since it is above the standard minimum of 47. The works by Ejeh and Aderemi, (2014) however, have cetane number (46.8374) which was lower than that obtained in this research. Thus its combustion is expected to be in moderate proportion to the combustion time necessary to give the required output should it be used to power any energy generating equipment or machine.

Saponification value (SV) is the number of milligrams of potassium hydroxide required to saponify $1 \mathrm{~g}$ of fat under the condition specified. It measure average molecular weight. Saponification value of the shea biodiesel was $184.18 \mathrm{mgKOH} / \mathrm{kg}$. This property is more important in oils that are being tested for suitability in soap making. SV of shea butter (181.98 $\mathrm{mgKOH} / \mathrm{Kg}$ ) and other oil properties are presented in Table 2, and are pointers to various uses of the shea fat including cosmetics and culinary dimensions.

Viscosity of a fluid is a measure of it resistance to deformation at a given rate. For liquid, it corresponds to the informal concept of thickness. Viscosity of the shea biodiesel was $2.66 \mathrm{~mm}^{2} \mathrm{~s}^{-}$ ${ }^{1}$ at $40^{0} \mathrm{C}$. This value agrees well with that $\left(2.88 \mathrm{~mm}^{2} \mathrm{~s}^{-1}\right)$ reported for another produced shea biodiesel by Odisu et al. (2019) and however, though within range, the value $\left(3.62 \mathrm{~mm}^{2} \mathrm{~s}^{-1}\right)$ by Datti et al. (2020) was quite higher than that of this research. These values are within the range 
(1.9 - 6.0) specified by American Society for Testing and Materials (ASTM) D6751 and (EN) 14214 International Standard (Jenvanitpanjakul, 2009). Differences though quite insignificant in the two shea biodiesel generated by Odisu et al. (2019) and of this work could be due to locality and climatic condition differences.

API gravity is the acronym for American Petroleum Institute gravity. It is an inverse measure that is used to determine the weight of petroleum liquid in comparison to water. API gravity of the shea biodiesel was 29.61. This parameter was necessary for calculating the cetane number.

\section{Conclusion}

Shea butter biodiesel of acceptable quality was successfully produced through transesterification in a 90 mins batch run using $\mathrm{KOH}$ as catalyst, and methanol at a reaction temperature of $70^{\circ} \mathrm{C}$. Shea biodiesel yield of $87 \%$ was achieved agreeing with previous works that shea fat is a good feedstock for biodiesel production. Majority of the characterized physicochemical properties are within the acceptable range of standard biodiesel. Shea butter biodiesel could thus be utilized as an addition in bio-based biodiesel for energy generation in machineries and various equipment.

\section{Declarations:}

\section{Ethics approval and consent to participate}

Not Applicable

\section{Consent for publication}

All the authors have given their consent through the corresponding author for this research work to be published under the Bioresources and Bioprocessing Journal.

\section{Availability of data and materials}

The data and materials collected were from the values and environment where the research was carried out. There is no dispute or ethical violation in both the data and materials used as recorded in the manuscript.

\section{Competing interests}

The authors declare that they have no competing interests.

\section{Funding}

This research work was not funded by any organization or institution. It is the sole efforts of the researchers.

\section{Authors Contribution}

IGO designed the study. EKD carried out the field/laboratory operations. Data analysis were by CSE and IGO. Supporting literature was by CSE. Preparation of manuscript was carried out by CSE, All authors read and approved the final manuscript. 


\section{Acknowledgement}

The authors acknowledge the assistance of Laboratory Technologists of Departments of Biochemisty and Chemistry of the Renaissance University Ugbawka, Enugu State, Nigeria.

\section{Authors' information (optional):}

Mr. I. G. Okoye M.Sc. is a Ph.D student of the University of Nigeria, Nsukka, Enugu State, Nigeria. He is a lecturer and Head of Biochemistry Department of Renaissance University, Ugbawka, Enugu, Nigeria. He has over 5 years lecturing and research experience and has published in quite a number of reputable peer reviewed journals.

Dr. C. S. Ezeonu is a Doctor of Biochemistry. He is a Lecturer with the Biochemistry Department of Federal University Wukari, Taraba State, Nigeria. He has over 10 years or research and lecturing experience and belongs to many learned societies and has published over 50 scientific papers in peer reviewed journals. He is actively involved in the academia and continuous research in the area of Industrial Biochemistry.

Miss. E. K. Danlami B.Sc. is a graduate of Biochemistry from Renaissance University, Ugbawka, Enugu, Nigeria. She is a good scholar and a promising researcher.

\section{References}

American Society for Testing and Materials (ASTM). (2002). Standard Specification for Biodiesel Fuel (B100) Blend Stock for Distillate Fuels. Designation D6751-02, ASTM International, West Conshohocken, PA.

Boerlage GD, Broeze JI (1990). Determination of Saponification, Iodine and Peroxide Value. Progress Report of Volunteer Group for Fuel Research Society of Automotive Engineers. 21:289-305.

Boerlage GD. and Broeze JI (1994). Determination of Saponification, Iodine and Peroxide Value .Progress Report of Volunteer Group for Fuel Research Society of Automotive Engineer. 21:231-232.

Datti Y, Musa I, Isma'il S, Mustapha A, Muhammad MS, Ado AS and Ahmad UU. (2020). Extraction, production and characterization of biodiesel from shea butter (Vitellaria paradoxa $\mathrm{C}$. F. Gaertn) Obtained from Hadejia, Jigawa State, Nigeria. GSC Biological and Pharmaceutical Sciences, 11(3), 208-215.

Ejeh J, Aderemi B (2014) Production of Biodiesel from Shea Butter Oil using Homogeneous Catalysts. Leonardo Journal of Sciences. 24:39-48.

Eneh MCC (2010) 'An overview of shea nut and Shea butter industry in nigeria' Paper presentation at the national seminar organised by Central Bank of Nigeria, in collaboration with 
Federal Ministry of Agric \& Rural Development, and Nigeria export promotion council (NEPC); Held at hydro hotels limited, minna, niger state, from $4-5$ August, 2010.

Jenvanitpanjakul P (2009) Establishment of the Guidelines for the Development of Biodiesel Standards in the APEC Region pg $6-8$

Odisu T, Akemu A, Obahiagbon KO, Anih EC (2019) Comparative Studies on the Production of Biodiesel from Shea Nut Oil by Acid Catalyzed and Supercritical Transesterification Processes. J. Appl. Sci. Environ. Manage. 23 (2) 349-357.

Onwuka, G.I (2018).food Analysis and Instrumentation - Theory and practices Pp 275300.Second Edition Naphtaly print Lagos Nigeria

Warra AA (2011) Cosmetic Potentials of African Shea Nut (Vitellaria Paradoxa) Butter. Current Research in Chemistry, 3(2):80-86

Wick WE (1985). Water content determination. Proceedings of Review Engineering Society $10: 225$.

Yaro MN, Bashir IA, Dauda A, Badamasi H (2019). Production of Biodiesel and Glycerol from Shea Butter Seed Oil at Different Operational Conditions. The Pharmaceutical and Chemical Journal, 6(3):93-98 


\section{Supplementary Files}

This is a list of supplementary files associated with this preprint. Click to download.

- GRAPHICALABSTRACTBIODIESEL.docx 